Prepared in cooperation with the Shoshone-Paiute Tribes of the Duck Valley Indian Reservation

\title{
Evaluation of Mercury in Rainbow Trout Collected from Duck Valley Indian Reservation Reservoirs, Southwestern Idaho and Northern Nevada, 2007, 2009, and 2013
}

Scientific Investigations Report 2015-5079 



\section{Evaluation of Mercuy in Rainbow Trout Collected from Duck Valley Indian Reservation Reservoirs, Southwestern Idaho and Northern Nevada, 2007, 2009, and 2013}

By Marshall L. Williams, Dorene E. MacCoy, and Terry R. Maret

Prepared in cooperation with the Shoshone-Paiute Tribes of the Duck Valley Indian Reservation

Scientific Investigations Report 2015-5079 


\title{
U.S. Department of the Interior SALLY JEWELL, Secretary
}

\section{U.S. Geological Survey Suzette M. Kimball, Acting Director}

\author{
U.S. Geological Survey, Reston, Virginia: 2015
}

For more information on the USGS - the Federal source for science about the Earth, its natural and living resources, natural hazards, and the environment—visit http://www.usgs.gov or call 1-888-ASK-USGS.

For an overview of USGS information products, including maps, imagery, and publications, visit http://www.usgs.gov/pubprod/.

Any use of trade, firm, or product names is for descriptive purposes only and does not imply endorsement by the U.S. Government.

Although this information product, for the most part, is in the public domain, it also may contain copyrighted materials as noted in the text. Permission to reproduce copyrighted items must be secured from the copyright owner.

Suggested citation:

Williams, M.L., MacCoy, D.E., and Maret, T.R., 2015, Evaluation of mercury in rainbow trout collected from Duck Valley Indian Reservation reservoirs, southwestern Idaho and northern Nevada, 2007, 2009, and 2013: U.S. Geological Survey Scientific Investigations Report 2015-5079, 18 p., http://dx.doi.org/10.3133/sir20155079.

ISSN 2328-0328 (online) 


\section{Contents}

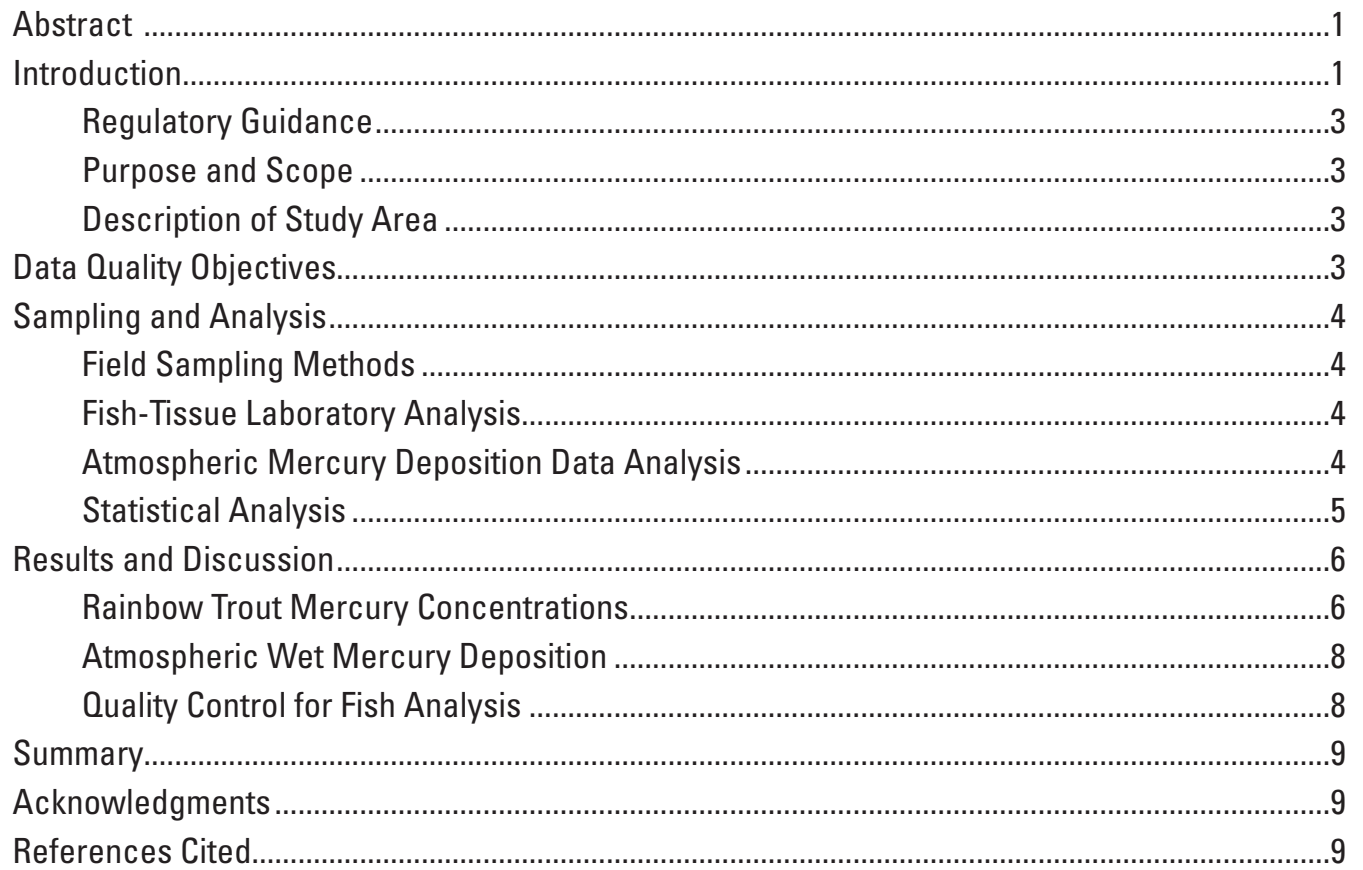

\section{Figures}

1. Map showing location of Duck Valley Indian Reservation reservoirs and Mercury Deposition Network sites (NV02 and NV99), southwestern Idaho and northern Nevada.

2. Graphs showing mercury concentration in fish tissue by length from Duck Valley Indian Reservation reservoirs and hatchery background samples from the Black Canyon Trout Farm, southwestern Idaho and northern Nevada, 2007, 2009, and 2013

3. Boxplots showing sample concentration by year for rainbow trout sampled from Duck Valley Indian Reservation reservoirs, southwestern Idaho and northern Nevada, 2007, 2009, and 2013

4. Graph showing annual wet mercury deposition rate at Mercury Deposition Network site NV02, Lesperance Ranch, Nevada, 2003-2013.

\section{Tables}

1. Statistical summary of annual sampling events for Duck Valley Indian Reservation reservoirs, southwestern Idaho and northern Nevada, 2007, 2009, and 2013 ..................6

2. Individual fish size, weight, and mercury concentration data, and statistical summaries for Duck Valley Indian Reservation reservoirs and hatchery background samples from the Black Canyon Trout Farm, southwestern Idaho and northern Nevada, 2007, 2009, and 2013.

3. Quality-control results for analysis of total mercury in fish from Duck Valley Indian Reservation reservoirs and hatchery background samples from the Black Canyon Trout Farm, southwestern Idaho and northern Nevada, 2007, 2009, and 2013. 


\section{Conversion Factors}

Inch/Pound to SI

\begin{tabular}{|c|c|c|}
\hline Multiply & By & To obtain \\
\hline \multicolumn{3}{|c|}{ Length } \\
\hline inch (in.) & 2.54 & centimeter $(\mathrm{cm})$ \\
\hline inch (in.) & 25.4 & millimeter (mm) \\
\hline \multicolumn{3}{|c|}{ Area } \\
\hline acre & 4,047 & square meter $\left(\mathrm{m}^{2}\right)$ \\
\hline acre & 0.004047 & square kilometer $\left(\mathrm{km}^{2}\right)$ \\
\hline square mile $\left(\mathrm{mi}^{2}\right)$ & 2.590 & square kilometer $\left(\mathrm{km}^{2}\right)$ \\
\hline \multicolumn{3}{|c|}{ Mass } \\
\hline ounce, avoirdupois (oz) & 28.35 & gram (g) \\
\hline pound, avoirdupois (lb) & 0.4536 & kilogram (kg) \\
\hline \multicolumn{3}{|l|}{ SI to Inch/Pound } \\
\hline Multiply & By & To obtain \\
\hline \multicolumn{3}{|c|}{ Length } \\
\hline centimeter $(\mathrm{cm})$ & 0.3937 & inch (in.) \\
\hline millimeter (mm) & 0.03937 & inch (in.) \\
\hline kilometer $(\mathrm{km})$ & 0.6214 & mile (mi) \\
\hline \multicolumn{3}{|c|}{ Mass } \\
\hline milligram (mg) & 0.00003527 & ounce, avoirdupois (oz) \\
\hline $\operatorname{gram}(\mathrm{g})$ & 0.03527 & ounce, avoirdupois (oz) \\
\hline kilogram (kg) & 2.205 & pound avoirdupois (lb) \\
\hline
\end{tabular}

\section{Abbreviations}

$\begin{array}{ll}\text { ANOVA } & \text { analysis of variance } \\ \text { CRM } & \text { certified reference material } \\ \text { Hg } & \text { mercury } \\ \text { IDEO } & \text { Idaho Department of Environmental Quality } \\ \text { IFCAP } & \text { Idaho Fish Consumption Advisory Program } \\ \text { IAEA } & \text { International Atomic Energy Agency } \\ \text { MDN } & \text { Mercury Deposition Network } \\ \text { MeHg } & \text { methylmercury } \\ \text { NADP } & \text { National Atmospheric Deposition Program } \\ \text { OC } & \text { quality-control } \\ \text { RPTE } & \text { reasonable potential to exceed } \\ \text { USEPA } & \text { U.S. Environmental Protection Agency } \\ \text { USGS } & \text { U.S. Geological Survey } \\ \text { USGS MRL } & \text { U.S. Geological Survey Mercury Research Laboratory }\end{array}$




\title{
Evaluation of Mercury in Rainbow Trout Collected from Duck Valley Indian Reservation Reservoirs, Southwestern Idaho and Northern Nevada, 2007, 2009, and 2013
}

\author{
By Marshall L. Williams, Dorene E. MacCoy, and Terry R. Maret
}

\section{Abstract}

The U.S. Geological Survey, in cooperation with the Shoshone-Paiute Tribes of the Duck Valley Indian Reservation, analyzed mercury $(\mathrm{Hg})$ concentration in rainbow trout (Oncorhynchus mykiss) collected from three reservoirs on the reservation (Mountain View, Lake Billy Shaw, and Sheep Creek) during sampling events in 2007, 2009, and 2013, to determine the risk of $\mathrm{Hg}$ exposure to Tribal members and the general public.

Mercury concentration in predatory fish tends to increase with fish length, and this tendency was true for rainbow trout in the reservoirs on the reservation $\left(\mathrm{r}^{2}=0.44-0.70\right)$. Mean (average) and median $\mathrm{Hg}$ concentrations in fish tissue were determined for each reservoir for each sample year. All $\mathrm{Hg}$ concentrations were less than the U.S. Environmental Protection Agency's water-quality criterion of 0.30 milligram per kilogram (mg/kg wet weight [ww]) and the Idaho Department of Environmental Quality's reasonable potential to exceed threshold of $0.24 \mathrm{mg} / \mathrm{kg}$. Idaho Department of Health and Welfare toxicologists determined that the $\mathrm{Hg}$ concentrations in rainbow trout in this study would not warrant a fish-consumption advisory for this species.

Throughout this report, statistical findings with a $p$-value of less than 0.05 are referred to as "significant." Mean Hg concentrations in fish-tissue samples collected from Mountain View Reservoir were higher in 2007 $(0.12 \mathrm{mg} / \mathrm{kg} \mathrm{ww})$ than in 2009 and 2013 (0.07 and $0.06 \mathrm{mg} / \mathrm{kg} \mathrm{ww}$, respectively), indicating a significant mean decrease. Mean Hg concentrations in fish-tissue samples collected from Lake Billy Shaw showed no significant differences among sample years $(2007,0.12 \mathrm{mg} / \mathrm{kg} \mathrm{ww}$; 2009, $0.07 \mathrm{mg} / \mathrm{kg}$ ww; 2013, $0.09 \mathrm{mg} / \mathrm{kg} \mathrm{ww}$ ). Mean $\mathrm{Hg}$ concentrations in fish-tissue samples collected from Sheep Creek Reservoir significantly increased in 2013 $(0.10 \mathrm{mg} / \mathrm{kg} \mathrm{ww})$ from concentrations in 2007 and 2009 ( 0.06 and $0.05 \mathrm{mg} / \mathrm{kg} \mathrm{ww}$, respectively). These temporal and spatial variations are not unexpected, as each body of water may differ in the factors and conditions affecting the rate of methylation and demethylation.
Coupled with the dynamic put-and-take fishery, the outcomes reflect the system complexities among reservoirs despite their fairly close proximity to one another. The influence of these other factors is evident when the analysis of atmospheric Hg deposition at Mercury Deposition Network site NV02 in northern Nevada showed no significant linear trend in wet $\mathrm{Hg}$ deposition rates for 2003-2013 (average 3.02 micrograms per square meter).

\section{Introduction}

The Duck Valley Indian Reservation spans the border of Idaho and Nevada (fig. 1). The reservation, established by executive order on April 16, 1877, is home to about 2,000 members of the Shoshone-Paiute Tribes (hereafter referred to as "the Tribes"). The Tribes manage three reservoirs (Mountain View, Lake Billy Shaw, and Sheep Creek Reservoirs) on the reservation as a subsistence fishery, and sport fishery for recreation and economic benefit. The Tribes have expressed concern about the potential for mercury $(\mathrm{Hg})$ contamination of these reservoirs and their aquatic biota. Research conducted in 2005 by Abbot and others (2008) from the U.S. Department of Energy Idaho National Laboratory showed elevated levels of atmospheric $\mathrm{Hg}$ entering southern Idaho from gold processing sites in northern Nevada. Average $\mathrm{Hg}$ concentrations of trout sampled from nearby Nevada waters in 2005 and 2006 were $0.09-0.17 \mathrm{mg} / \mathrm{kg}$ ww (Nevada Department of Wildlife, 2007). Because of mercury's potential toxicity to humans, the Tribes needed more information on the occurrence of $\mathrm{Hg}$ concentrations in their fishery to help determine if those concentrations posed a risk to Tribal members and the general public. To determine the bioaccumulation of $\mathrm{Hg}$ in the Tribes' rainbow trout fishery and the potential risk to the consumers, the U.S. Geological Survey (USGS) began monitoring $\mathrm{Hg}$ concentrations in rainbow trout in the reservation's three reservoirs in 2007, with additional sampling conducted in the 2009 and 2013. 


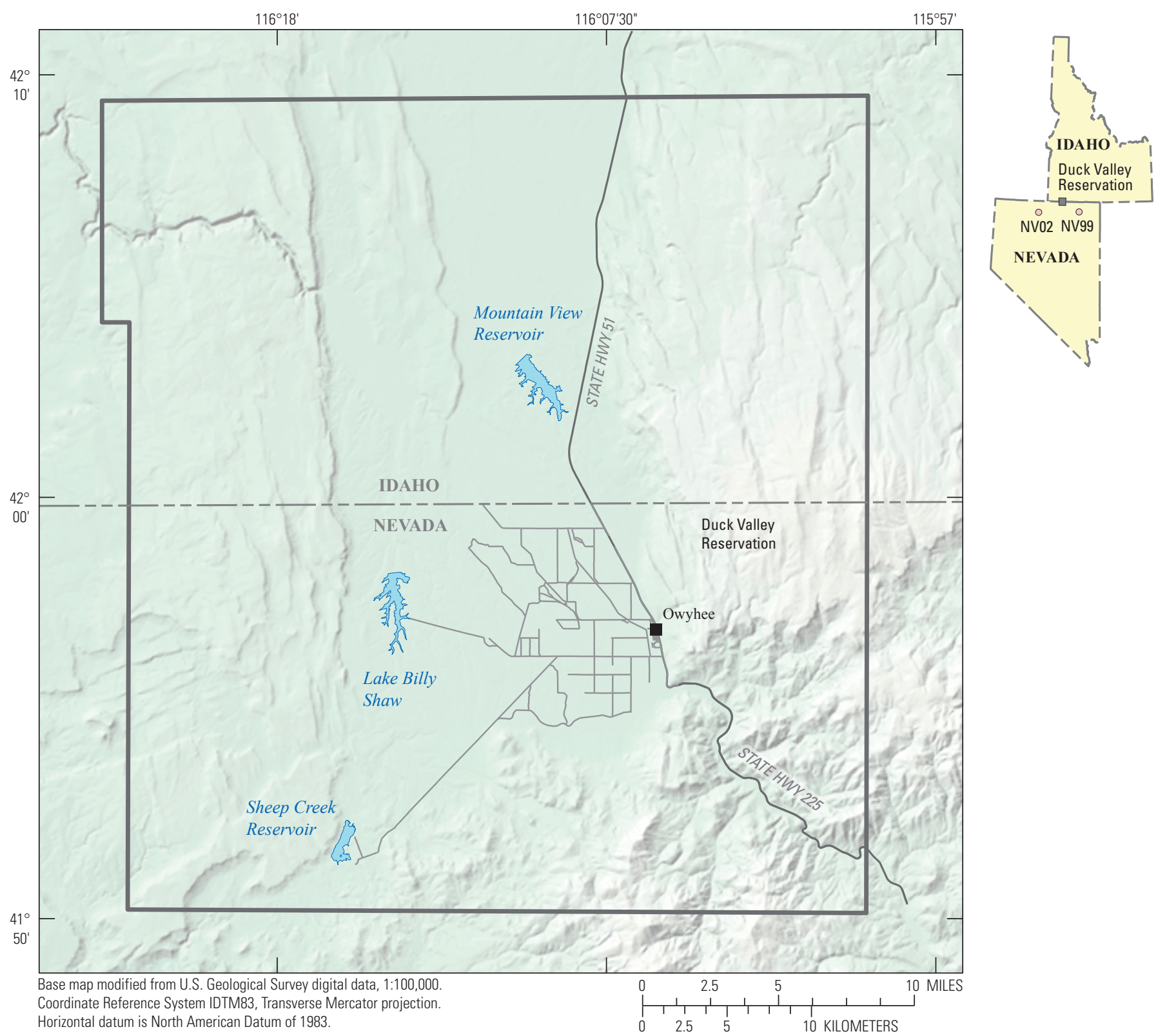

Figure 1. Location of Duck Valley Indian Reservation reservoirs and Mercury Deposition Network sites (NV02 and NV99), southwestern Idaho and northern Nevada.

Mercury is a global pollutant that ultimately makes its way into every aquatic ecosystem through the hydrologic cycle. Atmospheric deposition of inorganic Hg contributes the vast majority of $\mathrm{Hg}$ to aquatic systems as either dry fall or scavenged during precipitation events, although geologic sources and point-source pollution also may contribute to Hg loading (Rada and others, 1989; Fitzgerald and others, 1991; Kamman and Engstrom, 2002). Once it is in aquatic systems, inorganic Hg may become methylated through microbial sulfate and iron reduction (Fitzgerald and Lamborg, 2003; Fleming and others, 2006; Kerin and others, 2006).
Reservoirs are particularly prone to $\mathrm{Hg}$ methylation because of increased microbial activity that results from water-level fluctuations; they can also respond quickly to direct $\mathrm{Hg}$ deposition (Sorensen and others, 2005; Wiener and others, 2007; Brigham and others, 2014). Methylmercury (MeHg) is the more bioavailable and toxic form of $\mathrm{Hg}$; once $\mathrm{Hg}$ has moved through aquatic food chains into predatory fish, almost all $\mathrm{Hg}$ present in fish tissue is MeHg. In turn, sport fish that are most commonly captured and consumed by subsistence or recreational anglers tend to be predatory fish. 
As a result of these dynamics, risks of human exposure to $\mathrm{MeHg}$ are primarily through consumption of fish (U.S. Environmental Protection Agency, 2001). Sources of $\mathrm{Hg}$ often are not well quantified. However, they likely include atmospheric deposition, historical gold mining operations, and natural sources. The U.S. Environmental Protection Agency (USEPA, 2015) Toxic Release inventory for data from 2001 to 2013 shows that most Hg (stack) emissions in Nevada come from gold mining and processing facilities. Mercury often is released from thermal processes where it enters the air during the gold extraction process (Jones and Miller, 2005). Air emissions from these mining and processing facilities may travel great distances, affecting States throughout the Intermountain West. In 2001, USEPA toxic release inventory data showed that Nevada metal mining companies reported releasing about 9 percent of total U.S. mercury compounds as point source (stack) emissions. This amount has steadily decreased, becoming 6.5 percent of the total U.S. emissions in 2002, 3.6 percent in 2003 (Jones and Miller, 2005), and 1.4 percent in 2013. Overall, reported Hg mass from stack emissions attributed to mines and mine processing in Nevada has decreased from about $11,800 \mathrm{lb}$ in 2001 to $932 \mathrm{lb}$ in 2013, a 92 percent decrease (U.S. Environmental Protection Agency, 2015).

\section{Regulatory Guidance}

The USEPA recommended a water-quality criterion for $\mathrm{MeHg}$ expressed as a fish-tissue residue value (MeHg in fish tissue) of $0.30 \mathrm{mg} / \mathrm{kg}$ ww (U.S. Environmental Protection Agency, 2001). The MeHg criterion is based on fresh weight, appropriately indicating the nature of fish destined for human consumption. This criterion is based on protecting an adult consumer who eats an average of $17.5 \mathrm{~g}$ of fish per day, equivalent to about one 8-ounce serving every other week (U.S. Environmental Protection Agency, 2001; Idaho Department of Environmental Quality, 2005).

The Idaho Department of Environmental Quality (IDEQ) adopted the USEPA fish-tissue criterion and established a reasonable potential to exceed (RPTE) threshold designed to protect consumers that is 20 percent lower than the criterion or Hg greater than $0.24 \mathrm{mg} / \mathrm{kg}$ ww based on an average concentration of 10 fish from a receiving waterbody (Idaho Department of Environmental Quality, 2005). The Idaho Fish Consumption Advisory Program (IFCAP) applies an even lower action level of $0.22 \mathrm{mg} / \mathrm{kg}$ ww Hg, which is compared to the geometric mean $\mathrm{Hg}$ concentration of 10 fish of a single species collected from a single water body (lake or stream). IFCAP compares the action level and angling usage of each water body to determine if a consumption advisory should be issued.
For this study, total $\mathrm{Hg}$ is analyzed in place of $\mathrm{MeHg}$ in fish tissue for two reasons: (1) total $\mathrm{Hg}$ is easier and less costly for laboratories to determine than $\mathrm{MeHg}$, and (2) nearly all $\mathrm{Hg}$ present in fish muscle tissue is $\mathrm{MeHg}$ (Bloom, 1992; Hammerschmidt and others, 1999; Harris and others, 2003). In comparing fish-tissue results with the criterion, the analytical results for total $\mathrm{Hg}$ in the fish tissue should be interpreted as 100 percent $\mathrm{MeHg}$. For the remainder of this report, total $\mathrm{Hg}$ analyzed in fish tissue will be referred to as " $\mathrm{Hg}$ ".

\section{Purpose and Scope}

This report presents the results of the fish tissue analysis from samples collected from three reservoirs on the Duck Valley Indian Reservation in 2007, 2009, and 2013 in order to identify changes in fish-tissue $\mathrm{Hg}$ concentration within and between reservoirs for different sampling periods. A summary of annual atmospheric deposition rates measured at one of two northern Nevada Mercury Deposition Network (MDN) sites also is included. The scope of the investigation is limited to rainbow trout in the range of sizes people are likely to catch and eat from the reservoirs on the reservation.

\section{Description of Study Area}

Duck Valley Indian Reservation encompasses nearly 290,000 acres, of which 22,000 acres are wetlands. Three reservoirs were created on the reservation as a subsistence fishery, but they also provide the Tribes with a valued sport fishery for recreation and economic benefit (fig. 1). Mountain View Reservoir lies in the north-central part of the reservation and is about $2 \mathrm{mi}$ long with a surface area of about 630 acres. Lake Billy Shaw is about 9 mi southwest of Mountain View Reservoir and covers about 430 surface acres near the central area of the reservation. Sheep Creek Reservoir is $6 \mathrm{mi}$ south of Lake Billy Shaw in the south-west area of the reservation and covers about 855 surface acres. The perimeters of the reservoirs are shallow coves with riparian vegetation consisting of cattails, willows, and other aquatic vegetation; upland areas around the reservoirs primarily are sagebrush and grasses.

\section{Data Quality Objectives}

Data-quality objectives for sample collection, analysis, and reporting for this study are listed as follows, and provide $\mathrm{Hg}$ concentrations in fish-tissue data collected from Mountain View, Lake Billy Shaw, and Sheep Creek Reservoirs: 
1. Collect fish that represent the size range $(>25 \mathrm{~cm})$ likely to be captured and consumed by recreational or subsistence anglers near the sampling sites (table 2, at back of report).

2. Analyze hatchery trout provided by the Tribes from the Black Canyon Trout Farm in Grace, Idaho, as background samples for $\mathrm{Hg}$ concentration in stocked fish (table 2).

3. Use sample processing, handling, storage, shipping, and quality-assurance protocols sufficient to avoid introducing sample contamination or bias to the data.

4. Use laboratory analytical techniques that have sufficiently low detection limits to quantify $\mathrm{Hg}$ concentrations in fish tissue at less than $0.24 \mathrm{mg} / \mathrm{kg}$ ww (Idaho RPTE threshold).

5. Analyze quality-control samples to provide accuracy and precision information for the fish-tissue samples collected (table 3, at back of report). Quality control included analysis of certified reference material (CRM) to verify instrument calibration (accuracy), and analyses of triplicate fish-tissue samples as an assessment of repeatability (precision) for all sample years. In 2009 and 2013, field duplicates were added as an additional measure of quality control.

6. Following review, provide fish-tissue data to the Tribes, to the general public through the USGS National Water Information System, and in this report.

\section{Sampling and Analysis}

\section{Field Sampling Methods}

Fifteen rainbow trout (Oncorhynchus mykiss) were collected from each of the reservoirs (Mountain View, Lake Billy Shaw, and Sheep Creek Reservoirs) for each sample year $(2007,2009$, and 2013). One fish from Lake Billy Shaw in 2013 was not analyzed because of an external injury. Sampling in 2007 was conducted in late May, and samples in 2009 and 2013 were collected during the first week of June. Because one of the objectives was to sample a range of fish in sizes people are likely to catch and eat, experimental gill nets (mesh with several size openings) were used to reduce the effect of size selection based on a single mesh size (Hubert, 1983). These nets were used to collect samples, with the exception of fish collected on Sheep Creek Reservoir in 2007 when electrofishing was used. Fish were collected and stored in a live well on the boat during daily sampling events. Each fish was then measured, weighed, euthanized, and placed in separate clean, clear, zip-seal bags on wet ice; all fish were frozen within 24 hours of capture. Sample preparation followed guidelines in U.S. Environmental Protection Agency (2000) and Scudder and others (2008); final sample processing was conducted at the USGS Idaho Water Science Center's sample preparation area in Boise, Idaho. Individual samples, consisting of a 1-in. skinless fillet, were taken from each fish just below the dorsal fin (Goldstein and others, 1996). The samples were placed in self-sealing plastic bags, labeled, and frozen; they later were packed on dry ice for shipment to the USGS Mercury Research Laboratory (USGS MRL) in Middleton, Wisconsin, for analysis.

\section{Fish-Tissue Laboratory Analysis}

The USGS MRL provided analysis of $\mathrm{Hg}$ in fish tissue consistent with USEPA Method 7473 (U.S. Environmental Protection Agency, 2007). This method provides a minimum detection limit of $0.008 \mathrm{mg} / \mathrm{kg}$ dry weight (dw), based on a 20-50 mg sample size. The detection limit is sufficiently low to quantify $\mathrm{Hg}$ concentrations in fish tissue at less than $0.22 \mathrm{mg} / \mathrm{kg}$ ww required for IFCAP fish consumption advisory assessments.

\section{Atmospheric Mercury Deposition Data Analysis}

The USEPA operates two mercury wet deposition sites in northern Nevada (NV02 and NV99), upwind of the Duck Valley Indian Reservation as part of the National Atmospheric Deposition Program's (NADP) Mercury Deposition Network (MDN) (fig. 1). Wind vector and frequency analysis from a remote automated weather station on the reservation (Western Regional Climate Center, 2014) indicates that 44 percent of the prevailing winds are from the southwest compass quadrant, making site NV02, about 68 mi southwest of Sheep Creek Reservoir - the obvious choice for comparison of the $\mathrm{Hg}$ deposition rates in relation to reservoir fish samples. Details of the NADP methods and quality-assurance information are available online (National Atmospheric Deposition Program, 2014a). In general, Hg deposition data are collected at the MDN site and analyzed weekly for mercury deposition, summarized and normalized by precipitation, and reported to the public as an annual precipitation weighted wet $\mathrm{Hg}$ deposition rate (National Atmospheric Deposition Program, 2014b). Data from NADP for 2003-2013 were used to assess trends in $\mathrm{Hg}$ deposition on the reservation. Analysis of data outside of the tissue sampling year is helpful because elemental $\mathrm{Hg}$ may take years to enter into an aquatic system (Harris and others, 2007). Temporal trend testing was done through simple linear regression procedures using NCSS 10 data analysis software (NCSS Statistical Software, 2015). The annual depositional rate at site NV02 was regressed against year; a slope that is significant $(p<0.05)$ indicates a trend. 


\section{Statistical Analysis}

Analysis of variance (ANOVA) one-way parametric analysis was used to test the significance of difference in mean fish-tissue $\mathrm{Hg}$ concentrations for individual reservoirs among years. Because $\mathrm{Hg}$ concentration was positively correlated to fish length (fig. 2), Hg concentration was normalized by fish length, and then log transformed to remove much of the heteroscedasticity (unequal variance) of residuals. Data were assumed to be normally distributed. Significant differences were determined if the F-ratio exceeded the critical value $(p<0.05)$. For tests that indicated a significant difference, a multiple comparison test (Fisher's LSD, $\alpha=0.05$ ) was used to determine which years were significantly different. All ANOVA and multiple comparison statistical tests were done using NCSS 10 data analysis software (NCSS Statistical Software, 2015). A Mann-Kendall test also was run on the normalized and transformed data to determine monotonic change (trend) of $\mathrm{Hg}$ concentration in relation to time. The null hypothesis of "no change" is rejected if the S statistic is significantly different from $0(p<0.05)$. The Mann-Kendall statistical test was performed with a USGS software package (Helsel and others, 2006).

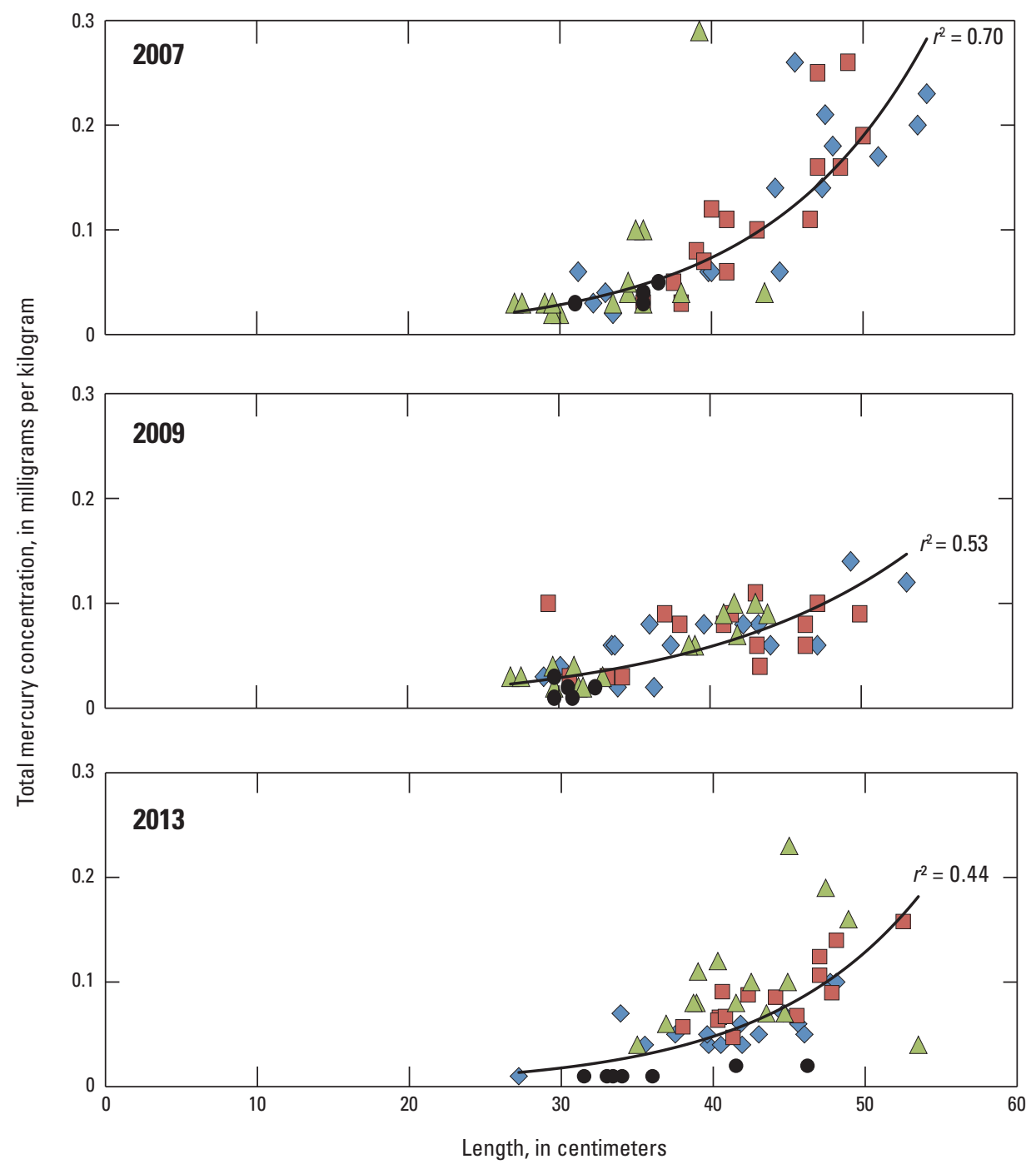

EXPLANATION

$\diamond \quad$ Mountain View Reservoir, Idaho

$\square \quad$ Lake Billy Shaw, Nevada

$\triangle \quad$ Sheep Creek Reservoir, Nevada

- Hatchery background samples from Black Canyon Trout Farm, Grace, Idaho

- Expon. (All Fish)

Figure 2. Mercury concentration in fish tissue by length from Duck Valley Indian Reservation reservoirs and hatchery background samples from the Black Canyon Trout Farm, southwestern Idaho and northern Nevada, 2007, 2009, and 2013. 


\section{Results and Discussion}

\section{Rainbow Trout Mercury Concentrations}

Predatory fish generally tend to bioaccumulate $\mathrm{Hg}$, with larger fish having higher $\mathrm{Hg}$ concentrations. Graphs of $\mathrm{Hg}$ concentration by fish length (fig. 2) show this principle for each of the sample years and each of the reservoirs. In aggregate, the correlation between fish length and $\mathrm{Hg}$ concentration was highest in $2007\left(\mathrm{r}^{2}=0.70\right)$, and decreased in subsequent years to $r^{2}=0.53$ (2009) and $r^{2}=0.44$ (2013).

Mean fish-tissue $\mathrm{Hg}$ concentrations significantly decreased in Mountain View Reservoir $(p=0.01)$ between 2007 (0.12 mg/kg ww) and 2009 (0.07 mg/kg ww) (table 1) and changed little between $2009(0.07 \mathrm{mg} / \mathrm{kg} \mathrm{ww})$ and 2013 $(0.06 \mathrm{mg} / \mathrm{kg} \mathrm{ww})$. Results of the Mann-Kendall trend test showed a significant decreasing trend in $\mathrm{Hg}$ concentration in Mountain View Reservoir between 2007 and 2013 ( $p<0.001$ ). Mean Hg concentration among the sample years in Lake Billy Shaw showed variance in $\mathrm{Hg}$ concentrations between sample years (2007, $0.12 \mathrm{mg} / \mathrm{kg} \mathrm{ww} ; 2009,0.07 \mathrm{mg} / \mathrm{kg}$ ww; $2013,0.09 \mathrm{mg} / \mathrm{kg} \mathrm{ww}$ ) with no significant difference between means $(p=0.14)$, and no temporal trend observed $(p=0.31)$. Mean Hg concentrations increased in Sheep Creek Reservoir $(p<0.01)$ between $2009(0.05 \mathrm{mg} / \mathrm{kg} \mathrm{ww})$ and 2013 $(0.10 \mathrm{mg} / \mathrm{kg} \mathrm{ww})$, with minimal change in concentration between 2007 (0.06 mg/kg ww) and 2009 (0.05 mg/kg ww) (table 1); this reservoir showed an increasing trend in $\mathrm{Hg}$ concentration $(p<0.01)$.

$\mathrm{Hg}$ concentrations exceeded the RPTE threshold of $0.24 \mathrm{mg} / \mathrm{kg}$ ww in only 3 of the 134 fish sampled in the reservoirs during the 3 sampling years, and did not exceed the IDEQ water-quality criterion of $0.30 \mathrm{mg} / \mathrm{kg}$ ww in any of the fish sampled in the reservoirs for any of the sampled years. In 2007, Hg concentrations exceeded the RPTE threshold in one fish from each of the reservoirs-Mountain View Reservoir (0.26 mg/kg ww); Lake Billy Shaw (0.26 mg/kg ww); and Sheep Creek Reservoir (0.29 mg/kg ww) (table 1, fig. 3). Hg concentrations did not exceed the RPTE threshold limit in any of the fish sampled in 2009 or 2013 (fig. 3). Idaho Department of Health and Welfare toxicologists determined that the $\mathrm{Hg}$ concentrations in rainbow trout in this study would not warrant a fish consumption advisory (Jim Vannoy, Idaho Department of Health and Welfare, written commun., December 11, 2009, and March 11, 2014).

Table 1. Statistical summary of annual sampling events for Duck Valley Indian Reservation reservoirs, southwestern Idaho and northern Nevada, 2007, 2009, and 2013.

[Site locations are shown in figure $1 . \mathrm{mg} / \mathrm{kg}$, milligram per killogram]

\begin{tabular}{|c|c|c|c|c|c|c|c|}
\hline \multirow[b]{2}{*}{$\begin{array}{c}\text { Sample } \\
\text { year }\end{array}$} & \multicolumn{3}{|c|}{ Mercury (mg/kg wet weight) } & \multirow[b]{2}{*}{$\begin{array}{l}\text { Standard } \\
\text { deviation }\end{array}$} & \multirow[b]{2}{*}{ Minimum } & \multirow[b]{2}{*}{ Maximum } & \multirow[b]{2}{*}{$\begin{array}{c}\text { Number of } \\
\text { samples }\end{array}$} \\
\hline & $\begin{array}{c}\text { Geometric } \\
\text { mean } \\
\text { per site }\end{array}$ & $\begin{array}{l}\text { Median } \\
\text { per site }\end{array}$ & $\begin{array}{c}\text { Mean } \\
\text { per site }\end{array}$ & & & & \\
\hline \multicolumn{8}{|c|}{ Mountain View Reservoir, Idaho } \\
\hline 2007 & 0.10 & 0.14 & 0.12 & 0.08 & 0.02 & 0.26 & 15 \\
\hline 2009 & 0.06 & 0.06 & 0.07 & 0.03 & 0.02 & 0.14 & 15 \\
\hline 2013 & 0.05 & 0.05 & 0.06 & 0.02 & 0.01 & 0.10 & 15 \\
\hline \multicolumn{8}{|c|}{ Lake Billy Shaw, Nevada } \\
\hline 2007 & 0.10 & 0.11 & 0.12 & 0.07 & 0.03 & 0.26 & 15 \\
\hline 2009 & 0.07 & 0.08 & 0.07 & 0.03 & 0.03 & 0.11 & 15 \\
\hline 2013 & 0.08 & 0.09 & 0.09 & 0.03 & 0.05 & 0.16 & 14 \\
\hline \multicolumn{8}{|c|}{ Sheep Creek Reservoir, Nevada } \\
\hline 2007 & 0.04 & 0.03 & 0.06 & 0.07 & 0.02 & 0.29 & 15 \\
\hline 2009 & 0.05 & 0.04 & 0.05 & 0.03 & 0.02 & 0.10 & 15 \\
\hline 2013 & 0.09 & 0.08 & 0.10 & 0.05 & 0.04 & 0.23 & 15 \\
\hline
\end{tabular}




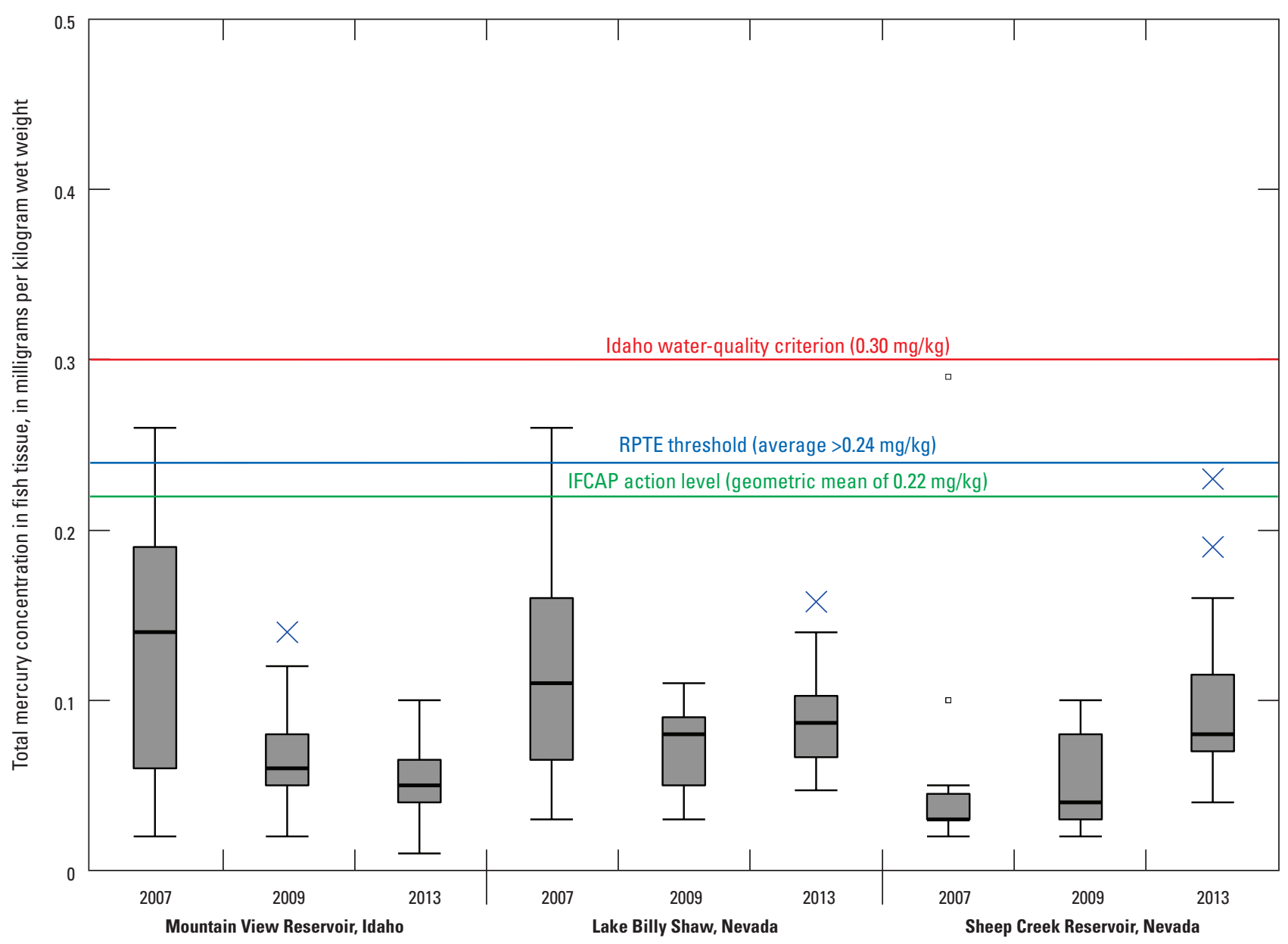

EXPLANATION

- Far-out values (values 3.0 times the IQR)

$X$ Outside values (values from 1.5 to 3.0 times the IQR)

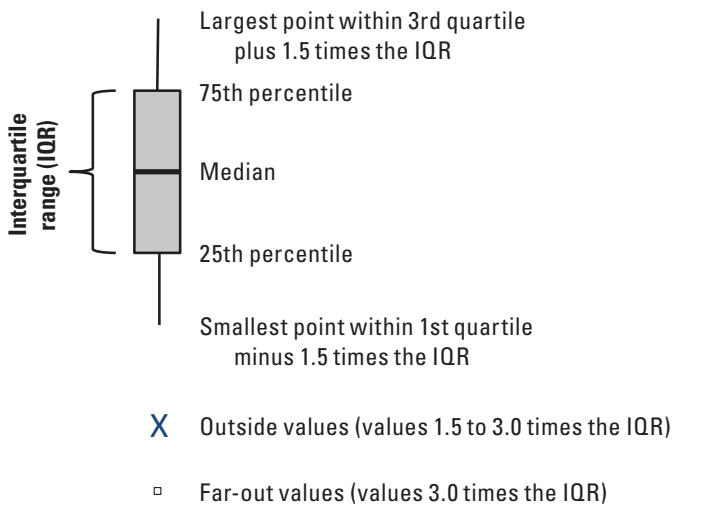

Figure 3. Sample concentration by year for rainbow trout sampled from Duck Valley Indian Reservation reservoirs, southwestern Idaho and northern Nevada, 2007, 2009, and 2013. RPTE threshold, reasonable potential to exceed 80 percent of the Idaho mercury water-quality criterion of 0.30 milligram per kilogram $(\mathrm{mg} / \mathrm{kg}$ ) wet weight mercury or greater than $0.24 \mathrm{mg} / \mathrm{kg}$ in an average of 10 fish; IFCAP action level, Idaho Fish Consumption Advisory Project recommends consideration of issuing a fish advisory when the geometric mean of mercury in 10 fish exceeds $0.22 \mathrm{mg} / \mathrm{kg}$ wet weight). 
The variation in $\mathrm{Hg}$ concentrations in fish tissue between years in each reservoir may be due to confounding factors such as water-level fluctuations, light penetration limitations due to turbidity from suspended sediments or an abundance of organic matter, or other factors affecting methylation and demethylation rates (Wiener and others, 2007). Changes in fish population because of fish stocking practices and fish harvesting also may create an artifact in data and exemplifies the complexity of the systems (Wiener and others, 2007). The Tribes also stock the reservoirs with large hatchery trout to reduce predation from bass in the reservoirs (Edmond Murrell, Shoshone-Paiute Tribes thenDirector of Fish, Wildlife and Parks Department, oral commun., 2012). These hatchery trout have low $\mathrm{Hg}$ concentrations, and may be the reason there is variability in the $\mathrm{Hg}$ concentration in larger fish (fig. 2). Information provided by the Tribes shows that they stocked 24,000 lb of catchable fish in late April and early May in each of the sample years. In 2007 and 2013, the hatchery stock was distributed equally among the three reservoirs, and ranged from 254 to $355 \mathrm{~mm}$ (10-14 in.) in length; in 2009, 16,000 lb was placed in Mountain View Reservoir, and 8,000 lb in Sheep Creek Reservoir, ranging from 254 to $330 \mathrm{~mm}$ (10-13 in.) in length (Jinwon Seo and Richard Edwards, Shoshone-Paiute Tribes Fish, Wildlife and Parks Department, written commun., 2015). The lengths should be considered estimates only, as one hatchery trout provided to the USGS for analysis in 2013 was $462 \mathrm{~mm}$ (18 in.) in length.

\section{Atmospheric Wet Mercury Deposition}

From 2003 to 2013, the rate of wet $\mathrm{Hg}$ deposition at site NV02 (average $3.02 \mu \mathrm{g} / \mathrm{m}^{2}$ ) showed no significant temporal linear trend $(p=0.79)$. Despite the decrease in total reported $\mathrm{Hg}$ compounds as point source (stack) emissions from Nevada mine operations from 2001 to 2013, there does not seem to be a decrease in the annual mercury deposition rate at site NV02 between 2003 and 2013 (fig. 4) (National Atmospheric Deposition Program, 2014b). This finding may be due to factors such as the locations of active gold processing sites in relation to regional wind patterns, or that the primary source of $\mathrm{Hg}$ to site $\mathrm{NV02}$ may be from the global atmospheric $\mathrm{Hg}$ pool. Although there was an elevated wet $\mathrm{Hg}$ deposition rate measured in $2009\left(5.66 \mu \mathrm{g} / \mathrm{m}^{2}\right)$, there was no significant linear trend between 2003 and 2013 (fig. 4).

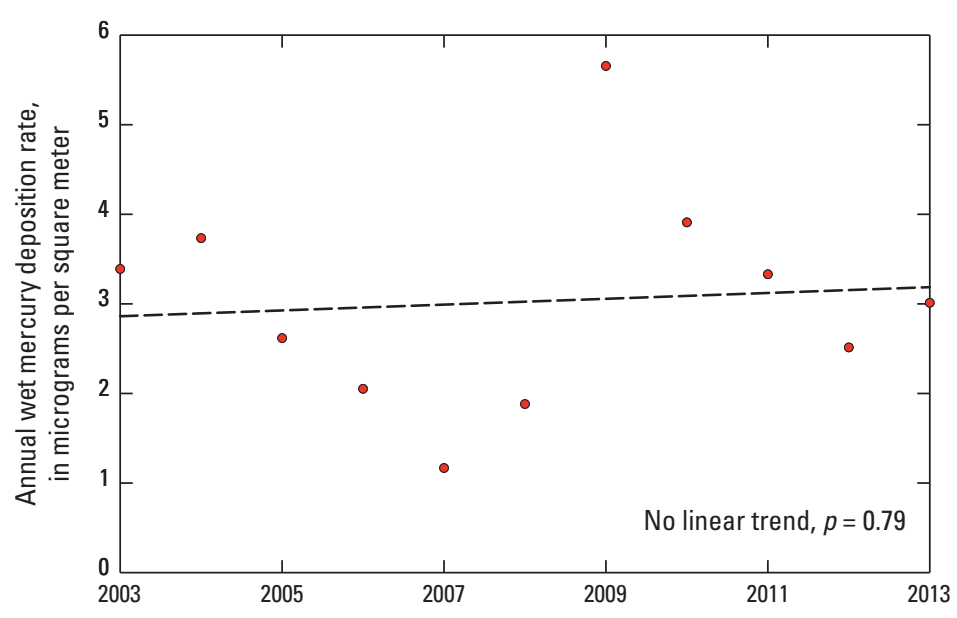

Figure 4. Annual wet mercury deposition rate at Mercury Deposition Network site NV02, Lesperance Ranch, Nevada, 2003-2013. Only complete data meeting National Atmospheric Deposition Program standards for data completion are plotted.

\section{Quality Control for Fish Analysis}

The USGS MRL has extensive quality-assurance and quality control procedures (U.S. Geological Survey, 2014). Briefly, the USGS MRL uses International Atomic Energy Agency certified reference material 407, or Institute for National Measurement Standards certified reference material DORM-2, to verify laboratory instrument calibration before each daily sample run (Institute for National Measurement Standards, 1993; International Atomic Energy Agency, 2003). To determine instrument accuracy, CRM is analyzed at the beginning of the sample processing day, after every 10 samples, and again at the end of the sample run. The relative percentage of difference of duplicates required by the USEPA is less than 24 percent (U.S. Environmental Protection Agency, 2002). Triplicates of sample material are analyzed to determine repeatability (precision) and should be within 15 percent of the relative standard deviation for replicate analysis to meet USGS MRL standards. For this project, field replicates were analyzed to determine bias in sample processing. The goal for relative percentage of difference in field replicates was established at less than 20 percent.

$\mathrm{Hg}$ concentrations in QC samples are presented with the environmental sample results (table 3 ). Table 3 also includes laboratory CRM results used to verify equipment calibration (accuracy), and triplicate sample results from individual fish to assess repeatability (precision) for all sample years. The accuracy of the data was within the USEPA standard of less than 24 percent of the most probable value for certified reference material for Hg (U.S. Environmental Protection Agency, 2002). 
Certified reference material recovery of $\mathrm{Hg}$ in QC samples ranged from 84.8 to 122 percent, within the required recovery of 76-124 percent of the theoretical value. The precision of the triplicate sample material was within 15 percent relative standard deviation in laboratory replicate analyses and ranged from 0.474 to 4.31 percent. Field duplicates also were analyzed as a measure of quality control, ranging from 0 to 14.7 percent, below the project goal of less than 20 percent relative percent difference.

\section{Summary}

The U.S. Geological Survey, in cooperation with the Shoshone-Paiute Tribes of the Duck Valley Indian Reservation, monitored mercury $(\mathrm{Hg})$ concentrations in rainbow trout to determine the risk of $\mathrm{Hg}$ exposure to Tribal members and the general public. Mean and median $\mathrm{Hg}$ concentrations were determined for 2007, 2009, and 2013, and all were less than the U.S. Environmental Protection Agency water-quality criterion of 0.30 milligram per kilogram $(\mathrm{mg} / \mathrm{kg})$ (wet weight, ww), and the Idaho Department of Environmental Quality reasonable potential to exceed threshold of $0.24 \mathrm{mg} / \mathrm{kg}$ ww. Idaho Department of Health and Welfare toxicologists determined that the $\mathrm{Hg}$ concentrations in rainbow trout in this study would not warrant a fishconsumption advisory for this species.

Analysis of fish-tissue samples from Mountain View Reservoir indicated a significant decrease ( $p=0.01$, analysis of variance test) in mean $\mathrm{Hg}$ concentrations between 2007 $(0.12 \mathrm{mg} / \mathrm{kg} \mathrm{ww})$ and $2009(0.07 \mathrm{mg} / \mathrm{kg} \mathrm{ww})$, and no significant difference between $2009(0.07 \mathrm{mg} / \mathrm{kg} \mathrm{ww})$ and 2013 (0.06 mg/kg ww). Results of the Mann-Kendall trend test showed a decreasing trend in $\mathrm{Hg}$ concentration over time $(p<0.001)$ for this reservoir. Mean Hg concentrations in Lake Billy Shaw indicated no significant difference between sample years $(p=0.14)$ and no significant trend $(p=0.31)$. Mean Hg concentrations in Sheep Creek Reservoir indicated little change between $2007(0.06 \mathrm{mg} / \mathrm{kg} \mathrm{ww})$ and $2009(0.05 \mathrm{mg} / \mathrm{kg} \mathrm{ww})$, whereas there was a significant difference $(p<0.01)$ between $2009(0.05 \mathrm{mg} / \mathrm{kg} \mathrm{ww})$ and 2013 $(0.10 \mathrm{mg} / \mathrm{kg} \mathrm{ww}) ; \mathrm{Hg}$ concentration in this reservoir showed an increasing trend $(p<0.01)$. There was no statistically significant linear trend indicating a relationship between a regional atmospheric source of $\mathrm{Hg}$ as measured at Mercury Deposition Network site NV02 and the Hg concentration increase in fish collected from Sheep Creek Reservoir during 2009 and 2013. However, there was an elevated annual atmospheric deposition rate in 2009 (5.66 micrograms per square meter $\left[\mu \mathrm{g} / \mathrm{m}^{2}\right]$ ), and terrestrial sources of $\mathrm{Hg}$ can take years or decades to enter aquatic ecosystems. Determining the source of Hg in Duck Valley Reservation's reservoirs would require additional study. Without attributing cause, or identifying a source, $\mathrm{Hg}$ concentrations in trout tend to follow a pattern of increasing $\mathrm{Hg}$ concentrations in fish tissue from north to south on the reservation. A decreasing trend was noted in Mountain View Reservoir $(p<0.00)$, no trend was found in Lake Billy Shaw $(p=0.31)$, and an increasing $\mathrm{Hg}$ trend was found in Sheep Creek Reservoir $(p<0.01)$. Overall, management of the fishery as well as other factors may affect the bioaccumulation of $\mathrm{Hg}$ in fish tissue. It was beyond the scope of this study to identify methylation processes that may be unique to each reservoir. Further study of $\mathrm{Hg}$ processing in the reservoirs may provide important clues for future management decisions concerning the Shoshone-Paiute Tribes fishery.

\section{Acknowledgments}

We would like to thank the Shoshone-Paiute Tribes and, in particular, Heather Lawrence, Director for the Tribal Environmental Program, and John Crum, a former staff member, for their contributions to this investigation. This project would not have been possible without their untiring effort over many years. We also would like to express our appreciation to the former Director of Fish, Wildlife and Parks, Edmond Murrell, the current Director, Dr. Jinwon Seo, and their respective staff personnel for the assistance they provided.

\section{References Cited}

Abbott, M.L., Lin, C.J., Martian, P., and Einerson, J.J., 2008, Atmospheric mercury near Salmon Falls Creek Reservoir in southern Idaho: Applied Geochemistry, v. 23, no. 3, p. 438-453, accessed December 29, 2014, at http://dx.doi. org/10.1016/j.apgeochem.2007.12.012.

Bloom, N.S., 1992, On the chemical form of mercury in edible fish and marine invertebrate tissue: Canadian Journal of Fisheries and Aquatic Sciences, v. 49, no. 5, p. 1,010-1,017, accessed December 29, 2014, at http://dx.doi.org/10.1139/ f92-113.

Brigham, M.E., Sandheinrich, M.B., Gay, D.A., Maki, R.P., Krabbenhoft, D.P., and Wiener, J.G., 2014, Lacustrine responses to decreasing wet mercury deposition ratesResults from a case study in northern Minnesota: Environmental Science and Technology, v. 48, no. 11, p. 6,115-6,123, accessed February 24, 2015, at http://dx.doi. org/10.1021/es500301a. 
Fleming, E.J., Mack, E.E., Green, P.G., and Nelson, D.C., 2006, Mercury Methylation from Unexpected SourcesMolybdate-inhibited freshwater sediments and an iron-reducing bacterium: Applied and Environmental Microbiology, v. 72, no. 1, p. 457-464, http://dx.doi. org/10.1128/AEM.72.1.457-464.2006.

Fitzgerald, W.F., and Lamborg, C.H., 2003, Geochemistry of mercury in the environment, in Turekian, K.K., and Holland, H.D., eds., Treatise on geochemistry: San Diego, Elsevier Pergamon, p. 107-148.

Fitzgerald, W.F., Mason, R., and Vandal, G., 1991, Atmospheric cycling and air-water exchange of mercury over mid-continental lacustrine regions: Water, Air, and Soil Pollution, v. 56, no. 1, p. 745-767.

Goldstein, R.M., Brigham, M.E., and Stauffer, J.C., 1996, Comparison of mercury concentrations in liver, muscle, whole bodies, and composites of fish from the Red River of the North: Canadian Journal of Fisheries and Aquatic Sciences, v. 53, no. 2, p. 244-252.

Hammerschmidt, C.R., Wiener, J.G., Frazier, B.E., and Rada, R.G., 1999, Methylmercury content of eggs in yellow perch related to maternal exposure in four Wisconsin lakes: Environmental Science and Technology, v. 33, no. 7, p. $999-1,003$.

Harris, H.H., Pickering, I.J., and George, G.N., 2003, The chemical form of mercury in fish: Science, v. 301, no. 5,637, p. 1,203, accessed December 29, 2014, at http:// dx.doi.org/10.1126/science. 1085941 .

Harris, R.C., Rudd, J.W.M., Amyot, M., Babiarz, C.L., Beaty, K.G., Blanchfield, P.J., Bodaly, R.A., Branfireun, B.A., Gilmour, C.C., Graydon, J.A., Heyes, A., Hintelmann, H., Hurley, J.P., Kelly, C.A., Krabbenhoft, D.P., Lindberg, S.E., Mason, R.P., Paterson, M.J., Podemski, C.L., Robinson, A., Sandilands, K.A., Southworth, G.R., St. Louis, V.L., and Tate, M.T., 2007, Whole-ecosystem study shows rapid fish-mercury response to changes in mercury deposition: Proceedings of the National Academy of Sciences, v. 104, no. 42, p. 16,586-16,591, accessed December 29, 2014, at http://dx.doi.org/10.1073/pnas.070418610.

Helsel, D.R., Mueller, D.K., and Slack, J.R., 2006, Computer program for the Kendall family of trend tests: U.S. Geological Survey Scientific Investigations Report 2005-5275, p. 4, http://pubs.usgs.gov/sir/2005/5275/.

Hubert, W.A., 1983, Passive capture techniques, in Nielsen, L.A., and Johnson, D.L., eds., Fisheries techniques: Bethesda, Maryland, American Fisheries Society, p. 95-122.
Idaho Department of Environmental Quality, 2005, Implementation guidance for the Idaho mercury water quality criteria: Boise, Idaho Department of Environmental Quality, p. 212, accessed October 29, 2014, at http://www. deq.state.id.us/water-quality/surface-water/mercury.aspx.

Institute for National Measurement Standards, 1993, DORM-2, dogfish muscle certified reference material for trace metals: Ottawa, Ontario, Canada, National Research Council of Canada, p. 4, accessed February 24, 2015, at http://www.nrc-cnrc.gc.ca/obj/doc/solutions-solutions/ advisory-consultatifs/crm-mrc/dorm_2_e.pdf.

International Atomic Energy Agency, 2003, Trace elements and methylmercury in fish tissue: Vienna, Austria, International Atomic Energy Agency Reference Sheet IAEA-407, accessed December 15, 2014, at http://www. iaea.org/nael/refmaterial/iaea407.pdf.

Jones, G., and Miller, G., 2005, Mercury and modern gold mining in Nevada_-Final report to the U.S. Environmental Protection Agency, Region IX: University of Nevada, Reno, Department of Environmental Sciences and Natural Resources, p. 41, http://www. chem.unep.ch/mercury/Trade\%20information/NRDCNEVADABYPRODUCTRECOVERYREPORT.pdf.

Kamman, N.C., and Engstrom, D.R., 2002, Historical and present fluxes of mercury to Vermont and New Hampshire lakes inferred from $\mathrm{Pb}$ dated sediment cores: Atmospheric Environment, v. 36, no. 10, p. 1599-1609.

Kerin, E.J., Gilmour, C.C., Roden, E., Suzuki, M.T., Coates, J.D., and Mason, R.P., 2006, Mercury Methylation by Dissimilatory Iron-Reducing Bacteria: Applied and Environmental Microbiology, v. 72, no. 12, p. 7919-7921, http://dx.doi.org/10.1128/AEM.01602-06.

National Atmospheric Deposition Program, 2014a, Mercury Deposition Network: Web site, accessed December 19, 2014, at http://nadp.sws.uiuc.edu/mdn/.

National Atmospheric Deposition Program, 2014b, MDN annual data: Web site, accessed December 19, 2014, at http://nadp.sws.uiuc.edu/data/mdn/annual.aspx.

NCSS Statistical Software, 2015, NCSS 10: Kaysville, Utah, NCSS, LLC.

Nevada Department of Wildlife, 2007, Mercury in the environment: Nevada Department of Wildlife Web site, accessed http://www.ndow.org/Fish/Fish_Safety/Mercury/. 
Rada, R., Wiener, J., Winfrey, M., and Powell, D., 1989, Recent increases in atmospheric deposition of mercury to north-central Wisconsin lakes inferred from sediment analyses: Archives of Environmental Contamination and Toxicology, v. 18, nos. 1-2, pp. 175-181, accessed December 29, 2014, at http://dx.doi.org/10.1007/ BF01056202.

Scudder, B.C., Chasar, L.C., DeWeese, L.R., Brigham, M.E., Wentz, D.A., and Brumbaugh, W.G., 2008, Procedures for collecting and processing aquatic invertebrates and fish for analysis of mercury as part of the national waterquality assessment program: U.S. Geological Survey Open-File Report 2008-1208, p. 35, http://pubs.usgs.gov/ of/2008/1208/.

Sorensen, J.A., Kallemeyn, L.W., and Sydor, M., 2005, Relationship between mercury accumulation in youngof-the-year yellow perch and water-level fluctuations: Environmental Science and Technology, v. 39, no. 23, p. 9,237-9,243, accessed October 28, 2014, at http://dx.doi. org/10.1021/es050471r.

U.S. Environmental Protection Agency, 2000, Guidance for assessing chemical contaminant data for use in fish advisories-Volume 1, Fish sampling and analysis (3rd ed.): U.S. Environmental Protection Agency, EPA 823-B00-007, 485 p., http:/water.epa.gov/scitech/swguidance/ fishshellfish/techguidance/.

U.S. Environmental Protection Agency, 2001, Water quality criterion for the protection of human healthMethylmercury: U.S. Environmental Protection Agency, EPA-823-R-10-001, 221 p., accessed March 10, 2014, at http://www.epa.gov/waterscience/criteria/methylmercury/.

U.S. Environmental Protection Agency, 2002, Method 1631, Revision E-Mercury in water by oxidation, purge, and trap, and cold vapor atomic fluorescence spectrometry: .U.S. Environmental Protection Agency, Office of Water, EPA821-R-02-019, p. 46, accessed December 29, 2014, at http:// water.epa.gov/scitech/methods/cwa/metals/mercury/index. cfm.
U.S. Environmental Protection Agency, 2007, Mercury in solids and solutions they thermal decomposition, amalgamation, and atomic absorption spectrophotometry: U.S. Environmental Protection Agency Method 7473 (SW-846), accessed December 29, 2014, at www.epa.gov/ osw/hazard/testmethods/sw846/pdfs/7473.pdf.

U.S. Environmental Protection Agency, 2015, Toxic Release Inventory (TRI) Program: Web site, accessed March 11, 2015, at http://www2.epa.gov/toxics-release-inventory-triprogram.

U.S. Geological Survey, 2014, U.S. Geological Survey Mercury Research Laboratory: U.S. Geological Survey Web site, accessed December 29, 2014, at http://wi.water.usgs. gov/mercury-lab/index.html.

Western Regional Climate Center, 2014, Remote automated weather stations USA climate archive: Desert Research Institute Web site, accessed December 29, 2014, at http:// www.raws.dri.edu/index.html.

Wiener, J.G., Bodaly, R.A., Brown, S.S., Lucotte, M., Newman, M.C., Porcella, D.B., Reash, R.J., and Swain, E.B., 2007, Monitoring and evaluating trends in methylmercury accumulation in aquatic biota, in Harris, R., Krabbenhoft, D.P., Mason, R., Murray, M.W., Reash, R., and Saltman, R., eds., Ecosystem responses to mercury contamination-Indicators of change: Boca Raton, Florida, CRC Press, p. 87-122. 
Table 2. Individual fish size, weight, and mercury concentration data, and statistical summaries for Duck Valley Indian Reservation reservoirs and hatchery background samples from the Black Canyon Trout Farm, southwestern Idaho and northern Nevada, 2007, 2009, and 2013.

[Site locations are shown in figure 1. Abbreviations: g, gram; mm, millimeter; mg/kg, milligram per kilogram]

\begin{tabular}{|c|c|c|c|c|c|c|c|}
\hline \multirow[b]{2}{*}{$\begin{array}{c}\text { Sample } \\
\text { date }\end{array}$} & \multirow[b]{2}{*}{ Time } & \multirow[b]{2}{*}{$\begin{array}{c}\text { Total } \\
\text { length } \\
(\mathrm{mm})\end{array}$} & \multirow[b]{2}{*}{$\begin{array}{c}\text { Weight } \\
\text { (g) }\end{array}$} & \multirow[b]{2}{*}{$\begin{array}{c}\text { Mercury } \\
\text { (mg/kg wet } \\
\text { weight) }\end{array}$} & \multicolumn{3}{|c|}{ Mercury (mg/kg wet weight) } \\
\hline & & & & & $\begin{array}{c}\text { Geometric } \\
\text { mean } \\
\text { per site }\end{array}$ & $\begin{array}{l}\text { Median } \\
\text { per site }\end{array}$ & $\begin{array}{c}\text { Mean } \\
\text { per site }\end{array}$ \\
\hline \multicolumn{8}{|c|}{ Mountain View Reservoir, Idaho } \\
\hline \multirow[t]{15}{*}{$05-21-07$} & 0830 & 400 & 747 & 0.06 & 0.10 & 0.14 & 0.12 \\
\hline & 0831 & 398 & 651 & 0.06 & & & \\
\hline & 0832 & 510 & 1,522 & 0.17 & & & \\
\hline & 0833 & 536 & 1,642 & 0.19 & & & \\
\hline & 0834 & 480 & 1,376 & 0.19 & & & \\
\hline & 0835 & 455 & 1,075 & 0.26 & & & \\
\hline & 0836 & 442 & 884 & 0.14 & & & \\
\hline & 0837 & 445 & 946 & 0.06 & & & \\
\hline & 0838 & 473 & 1,195 & 0.14 & & & \\
\hline & 0839 & 542 & 1,601 & 0.23 & & & \\
\hline & 0840 & 475 & 1,207 & 0.22 & & & \\
\hline & 0841 & 330 & 446 & 0.04 & & & \\
\hline & 0842 & 335 & 412 & 0.02 & & & \\
\hline & 0843 & 322 & 373 & 0.03 & & & \\
\hline & 0844 & 312 & 337 & 0.06 & & & \\
\hline \multirow[t]{15}{*}{ 06-01-09 } & 1200 & 471 & 1,153 & 0.06 & 0.06 & 0.06 & 0.07 \\
\hline & 1201 & 493 & 1,289 & 0.14 & & & \\
\hline & 1202 & 374 & 576 & 0.06 & & & \\
\hline & 1203 & 396 & 711 & 0.08 & & & \\
\hline & 1204 & 530 & 1,912 & 0.12 & & & \\
\hline & 1205 & 363 & 529 & 0.02 & & & \\
\hline & 1206 & 339 & 406 & 0.02 & & & \\
\hline & 1207 & 360 & 495 & 0.08 & & & \\
\hline & 1208 & 337 & 486 & 0.06 & & & \\
\hline & 1209 & 335 & 460 & 0.06 & & & \\
\hline & 1210 & 422 & 757 & 0.08 & & & \\
\hline & 1211 & 301 & 318 & 0.04 & & & \\
\hline & 1212 & 290 & 359 & 0.03 & & & \\
\hline & 1213 & 440 & 846 & 0.05 & & & \\
\hline & 1214 & 432 & 944 & 0.08 & & & \\
\hline \multirow{15}{*}{ 06-04-13 } & 928 & 272 & 298 & 0.01 & 0.05 & 0.05 & 0.06 \\
\hline & 929 & 481 & 1,174 & 0.10 & & & \\
\hline & 930 & 418 & 894 & 0.06 & & & \\
\hline & 931 & 477 & 1,368 & 0.10 & & & \\
\hline & 932 & 419 & 890 & 0.04 & & & \\
\hline & 933 & 396 & 730 & 0.05 & & & \\
\hline & 934 & 355 & 575 & 0.04 & & & \\
\hline & 935 & 405 & 805 & 0.04 & & & \\
\hline & 936 & 375 & 646 & 0.05 & & & \\
\hline & 937 & 460 & 1,080 & 0.05 & & & \\
\hline & 938 & 446 & 1,079 & 0.07 & & & \\
\hline & 939 & 339 & 810 & 0.07 & & & \\
\hline & 940 & 456 & 1,224 & 0.06 & & & \\
\hline & 941 & 430 & 1,022 & 0.05 & & & \\
\hline & 942 & 397 & 882 & 0.04 & & & \\
\hline
\end{tabular}


Table 2. Individual fish size, weight, and mercury concentration data, and statistical summaries for Duck Valley Indian Reservation reservoirs and hatchery background samples from the Black Canyon Trout Farm, southwestern Idaho and northern Nevada, 2007, 2009, and 2013.—Continued

\begin{tabular}{|c|c|c|c|c|c|c|c|}
\hline \multirow[b]{2}{*}{$\begin{array}{c}\text { Sample } \\
\text { date }\end{array}$} & \multirow[b]{2}{*}{ Time } & \multirow[b]{2}{*}{$\begin{array}{c}\text { Total } \\
\text { length } \\
(\mathrm{mm})\end{array}$} & \multirow[b]{2}{*}{$\begin{array}{l}\text { Weight } \\
\text { (g) }\end{array}$} & \multirow[b]{2}{*}{$\begin{array}{c}\text { Mercury } \\
\text { (mg/kg wet } \\
\text { weight) }\end{array}$} & \multicolumn{3}{|c|}{ Mercury (mg/kg wet weight) } \\
\hline & & & & & $\begin{array}{c}\text { Geometric } \\
\text { mean } \\
\text { per site }\end{array}$ & $\begin{array}{l}\text { Median } \\
\text { per site }\end{array}$ & $\begin{array}{c}\text { Mean } \\
\text { per site }\end{array}$ \\
\hline \multicolumn{8}{|c|}{ Lake Billy Shaw, Nevada } \\
\hline \multirow[t]{15}{*}{$05-22-07$} & 1400 & 395 & 605 & 0.07 & 0.10 & 0.11 & 0.12 \\
\hline & 1401 & 490 & 958 & 0.26 & & & \\
\hline & 1402 & 470 & 1,150 & 0.25 & & & \\
\hline & 1403 & 410 & 724 & 0.06 & & & \\
\hline & 1404 & 430 & 830 & 0.10 & & & \\
\hline & 1405 & 465 & 940 & 0.11 & & & \\
\hline & 1406 & 485 & 1,030 & 0.16 & & & \\
\hline & 1407 & 380 & 604 & 0.03 & & & \\
\hline & 1408 & 355 & 462 & 0.03 & & & \\
\hline & 1409 & 375 & 600 & 0.05 & & & \\
\hline & 1410 & 400 & 665 & 0.12 & & & \\
\hline & 1411 & 410 & 745 & 0.10 & & & \\
\hline & 1412 & 500 & 1,150 & 0.19 & & & \\
\hline & 1413 & 470 & 1,060 & 0.16 & & & \\
\hline & 1414 & 390 & 675 & 0.08 & & & \\
\hline \multirow[t]{15}{*}{ 06-02-09 } & 1200 & 499 & 1,349 & 0.09 & 0.07 & 0.08 & 0.07 \\
\hline & 1201 & 414 & 685 & 0.09 & & & \\
\hline & 1202 & 463 & 922 & 0.08 & & & \\
\hline & 1203 & 431 & 805 & 0.06 & & & \\
\hline & 1204 & 409 & 688 & 0.08 & & & \\
\hline & 1205 & 293 & 292 & 0.10 & & & \\
\hline & 1206 & 380 & 498 & 0.08 & & & \\
\hline & 1207 & 370 & 405 & 0.09 & & & \\
\hline & 1208 & 433 & 775 & 0.04 & & & \\
\hline & 1209 & 342 & 438 & 0.03 & & & \\
\hline & 1210 & 471 & 973 & 0.10 & & & \\
\hline & 1211 & 332 & 380 & 0.03 & & & \\
\hline & 1212 & 463 & 1,053 & 0.06 & & & \\
\hline & 1213 & 307 & 329 & 0.03 & & & \\
\hline & 1214 & 430 & 1,099 & 0.11 & & & \\
\hline \multirow[t]{14}{*}{$06-05-13$} & 946 & 455 & 894 & 0.07 & 0.08 & 0.09 & 0.09 \\
\hline & 947 & 470 & 1,073 & 0.07 & & & \\
\hline & 949 & 380 & 1,190 & 0.12 & & & \\
\hline & 951 & 403 & 630 & 0.06 & & & \\
\hline & 952 & 478 & 880 & 0.06 & & & \\
\hline & 953 & 413 & 1,196 & 0.09 & & & \\
\hline & 954 & 481 & 792 & 0.05 & & & \\
\hline & 956 & 525 & 1,345 & 0.14 & & & \\
\hline & 957 & 404 & 1,400 & 0.16 & & & \\
\hline & 958 & 423 & 680 & 0.07 & & & \\
\hline & 959 & 470 & 825 & 0.09 & & & \\
\hline & 1000 & 441 & 1,094 & 0.11 & & & \\
\hline & 1001 & 406 & 887 & 0.09 & & & \\
\hline & 1003 & 272 & 837 & 0.09 & & & \\
\hline
\end{tabular}


Table 2. Individual fish size, weight, and mercury concentration data, and statistical summaries for Duck Valley Indian Reservation reservoirs and hatchery background samples from the Black Canyon Trout Farm, southwestern Idaho and northern Nevada, 2007, 2009, and 2013.-Continued

\begin{tabular}{|c|c|c|c|c|c|c|c|}
\hline \multirow[b]{2}{*}{$\begin{array}{c}\text { Sample } \\
\text { date }\end{array}$} & \multirow[b]{2}{*}{ Time } & \multirow[b]{2}{*}{$\begin{array}{c}\text { Total } \\
\text { length } \\
\text { (mm) }\end{array}$} & \multirow[b]{2}{*}{$\begin{array}{l}\text { Weight } \\
\text { (g) }\end{array}$} & \multirow[b]{2}{*}{$\begin{array}{c}\text { Mercury } \\
\text { (mg/kg wet } \\
\text { weight) }\end{array}$} & \multicolumn{3}{|c|}{ Mercury (mg/kg wet weight) } \\
\hline & & & & & $\begin{array}{c}\text { Geometric } \\
\text { mean } \\
\text { per site }\end{array}$ & $\begin{array}{l}\text { Median } \\
\text { per site }\end{array}$ & $\begin{array}{c}\text { Mean } \\
\text { per site }\end{array}$ \\
\hline \multicolumn{8}{|c|}{ Sheep Creek Reservoir, Nevada } \\
\hline \multirow{15}{*}{$05-22-07$} & 1600 & 335 & 418 & 0.03 & 0.04 & 0.03 & 0.06 \\
\hline & 1601 & 392 & 568 & 0.29 & & & \\
\hline & 1602 & 295 & 315 & 0.03 & & & \\
\hline & 1603 & 345 & 430 & 0.05 & & & \\
\hline & 1604 & 380 & 646 & 0.04 & & & \\
\hline & 1605 & 345 & 464 & 0.04 & & & \\
\hline & 1606 & 350 & 386 & 0.10 & & & \\
\hline & 1607 & 435 & 834 & 0.03 & & & \\
\hline & 1608 & 355 & 418 & 0.10 & & & \\
\hline & 1609 & 335 & 390 & 0.03 & & & \\
\hline & 1610 & 295 & 270 & 0.02 & & & \\
\hline & 1611 & 300 & 294 & 0.02 & & & \\
\hline & 1612 & 290 & 252 & 0.03 & & & \\
\hline & 1613 & 275 & 228 & 0.03 & & & \\
\hline & 1614 & 270 & 210 & 0.03 & & & \\
\hline \multirow[t]{15}{*}{ 06-03-09 } & 1200 & 409 & 693 & 0.09 & 0.05 & 0.04 & 0.05 \\
\hline & 1201 & 430 & 867 & 0.10 & & & \\
\hline & 1202 & 418 & 761 & 0.07 & & & \\
\hline & 1203 & 416 & 873 & 0.10 & & & \\
\hline & 1204 & 386 & 607 & 0.06 & & & \\
\hline & 1205 & 329 & 409 & 0.03 & & & \\
\hline & 1206 & 390 & 723 & 0.06 & & & \\
\hline & 1207 & 310 & 357 & 0.04 & & & \\
\hline & 1208 & 316 & 372 & 0.02 & & & \\
\hline & 1209 & 275 & 205 & 0.02 & & & \\
\hline & 1210 & 297 & 276 & 0.02 & & & \\
\hline & 1211 & 268 & 216 & 0.03 & & & \\
\hline & 1212 & 313 & 326 & 0.02 & & & \\
\hline & 1213 & 296 & 264 & 0.04 & & & \\
\hline & 1214 & 438 & 806 & 0.09 & & & \\
\hline \multirow[t]{15}{*}{$06-06-13$} & 957 & 425 & 762 & 0.10 & 0.09 & 0.08 & 0.10 \\
\hline & 959 & 447 & 1,010 & 0.07 & & & \\
\hline & 1000 & 535 & 1,258 & 0.04 & & & \\
\hline & 1001 & 450 & 1,069 & 0.23 & & & \\
\hline & 1002 & 390 & 704 & 0.11 & & & \\
\hline & 1003 & 387 & 584 & 0.08 & & & \\
\hline & 1004 & 403 & 638 & 0.12 & & & \\
\hline & 1006 & 350 & 398 & 0.04 & & & \\
\hline & 1007 & 489 & 1,340 & 0.16 & & & \\
\hline & 1008 & 389 & 565 & 0.08 & & & \\
\hline & 1009 & 449 & 887 & 0.10 & & & \\
\hline & 1010 & 435 & 783 & 0.07 & & & \\
\hline & 1011 & 369 & 552 & 0.06 & & & \\
\hline & 1012 & 474 & 1,155 & 0.19 & & & \\
\hline & 1013 & 415 & 710 & 0.08 & & & \\
\hline
\end{tabular}


Table 2. Individual fish size, weight, and mercury concentration data, and statistical summaries for Duck Valley Indian Reservation reservoirs and hatchery background samples from the Black Canyon Trout Farm, southwestern Idaho and northern Nevada, 2007, 2009, and 2013.-Continued

\begin{tabular}{|c|c|c|c|c|c|c|c|}
\hline \multirow[b]{2}{*}{$\begin{array}{c}\text { Sample } \\
\text { date }\end{array}$} & \multirow[b]{2}{*}{ Time } & \multirow[b]{2}{*}{$\begin{array}{c}\text { Total } \\
\text { length } \\
(\mathrm{mm})\end{array}$} & \multirow[b]{2}{*}{$\begin{array}{c}\text { Weight } \\
\text { (g) }\end{array}$} & \multirow[b]{2}{*}{$\begin{array}{c}\text { Mercury } \\
\text { (mg/kg wet } \\
\text { weight) }\end{array}$} & \multicolumn{3}{|c|}{ Mercury (mg/kg wet weight) } \\
\hline & & & & & $\begin{array}{c}\text { Geometric } \\
\text { mean } \\
\text { per site }\end{array}$ & $\begin{array}{l}\text { Median } \\
\text { per site }\end{array}$ & $\begin{array}{c}\text { Mean } \\
\text { per site }\end{array}$ \\
\hline \multicolumn{8}{|c|}{ Black Canyon Trout Farm, Grace, Idaho } \\
\hline \multirow{5}{*}{ 05-04-07 } & 1215 & 355 & 500 & 0.03 & 0.04 & 0.04 & 0.04 \\
\hline & 1216 & 310 & 326 & 0.03 & & & \\
\hline & 1217 & 355 & 532 & 0.04 & & & \\
\hline & 1218 & 355 & 548 & 0.04 & & & \\
\hline & 1219 & 365 & 586 & 0.05 & & & \\
\hline \multirow[t]{5}{*}{ 04-22-09 } & 1200 & 297 & 240 & 0.01 & 0.02 & 0.02 & 0.02 \\
\hline & 1201 & 324 & 275 & 0.02 & & & \\
\hline & 1202 & 309 & 245 & 0.01 & & & \\
\hline & 1203 & 297 & 235 & 0.03 & & & \\
\hline & 1204 & 306 & 245 & 0.01 & & & \\
\hline \multirow[t]{7}{*}{$05-21-13$} & 1125 & 330 & 365 & 0.01 & 0.01 & 0.01 & 0.01 \\
\hline & 1130 & 360 & 505 & 0.01 & & & \\
\hline & 1131 & 315 & 290 & 0.01 & & & \\
\hline & 1132 & 334 & 450 & 0.01 & & & \\
\hline & 1133 & 415 & 690 & 0.02 & & & \\
\hline & 1134 & 462 & 1,070 & 0.02 & & & \\
\hline & 1135 & 340 & 425 & 0.01 & & & \\
\hline
\end{tabular}


Table 3. Quality-control results for analysis of total mercury in fish from Duck Valley Indian Reservation reservoirs and hatchery background samples from the Black Canyon Trout Farm, southwestern Idaho and northern Nevada, 2007, 2009 , and 2013.

[Certified reference material from the International Atomic Energy Agency (IAEA), laboratory identification number beginning with International Atomic Energy Agency (2003); a description of IAEA-407 is available at http://www.iaea.org/nael/refmaterial/iaea407.pdf. Certified reference material from the Institute for National Measurement Standards, National Research Council of Canada, laboratory identification number beginning with DORM-2; a description of DORM-2 is available at http://www.nrc-cnrc.gc.ca/obj/doc/solutions-solutions/advisory-consultatifs/crm-mrc/dorm_2_e.pdf. Triplicate samples from a single fish at a sampling site (laboratory identification samples beginning with MSC) were analyzed separate from the original sample for laboratory method repeatability (precision) and reported as relative standard deviation (RSD), RSD = Standard deviation of the three replicate concentrations divided by the average of those replicates. Field duplicates are samples from a single specimen collected as an assessment of quality control. Results are reported as relative percent difference (RPD), where $\left\{\left(\mathrm{x}_{1}-\mathrm{x}_{2}\right) /\left[\mathrm{x}_{1}+\mathrm{x}_{2}\right) / 2\right] 100$, and $\mathrm{x}=$ sample concentration. Abbreviation: ng/g, nanograms per gram $]$

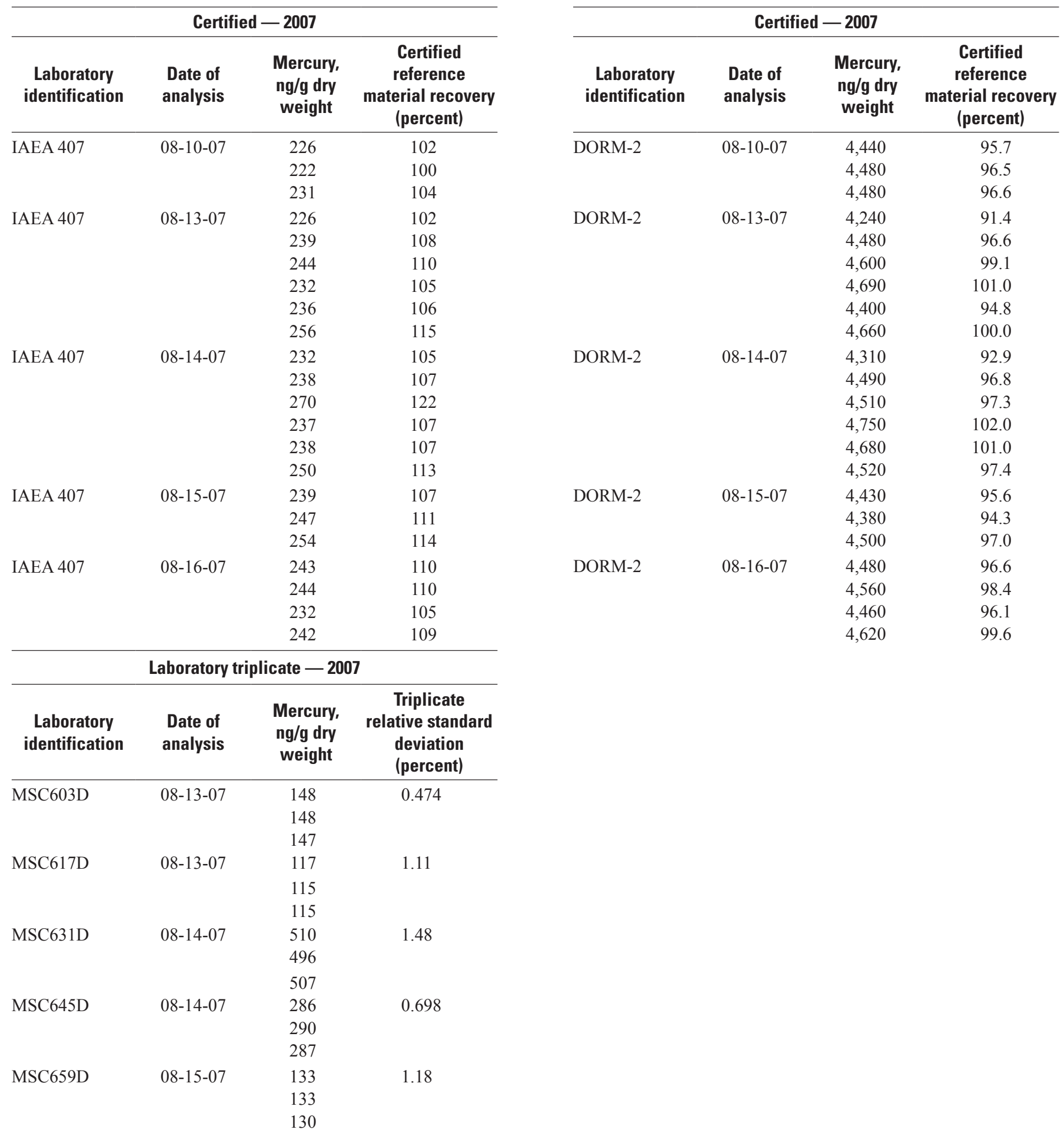


Table 3

Table 3. Quality-control results for analysis of total mercury in fish from Duck Valley Indian Reservation reservoirs and hatchery background samples from the Black Canyon Trout Farm, southwestern Idaho and northern Nevada, 2007, 2009, and 2013. - Continued

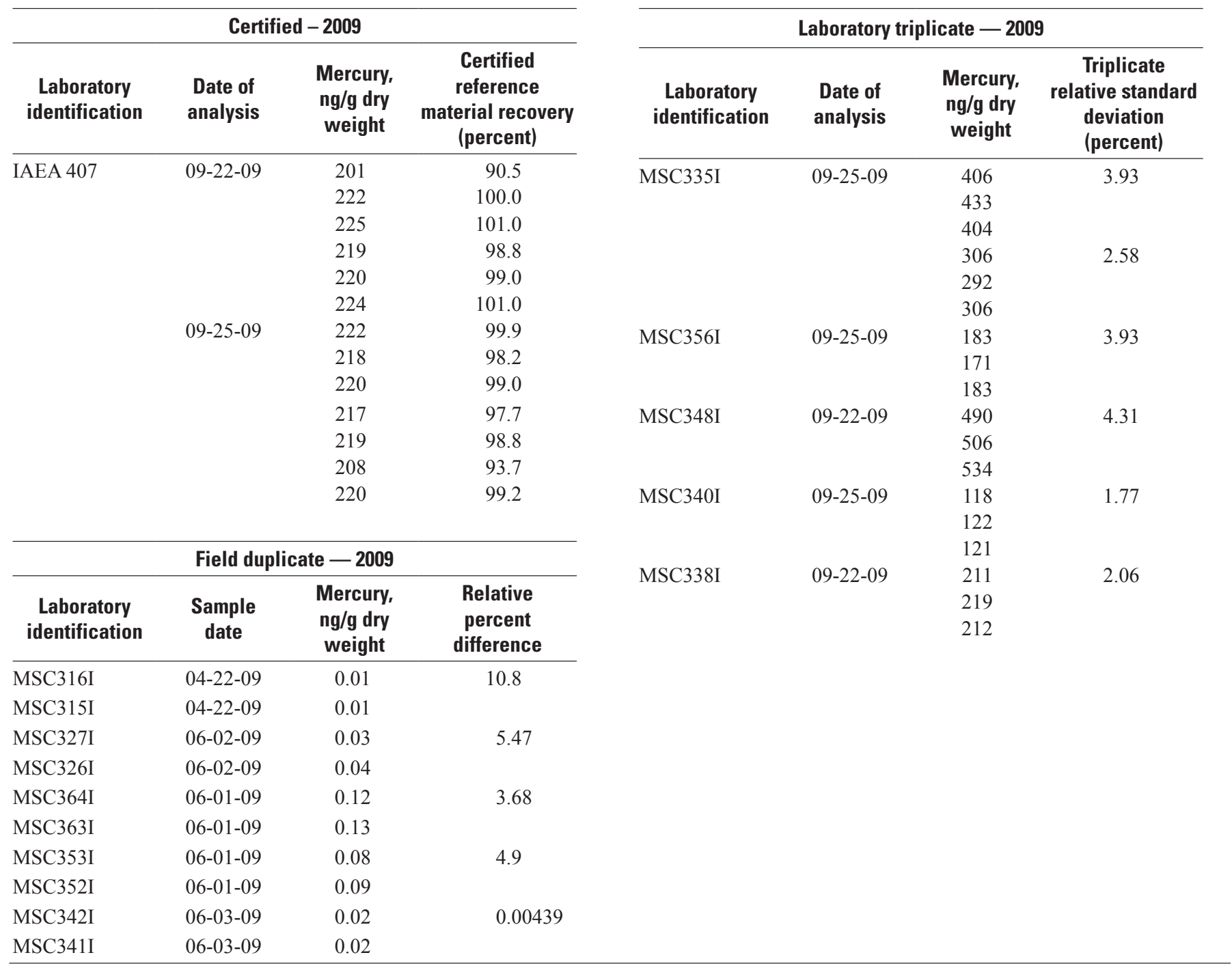


Table 3. Quality-control results for analysis of total mercury in fish from Duck Valley Indian Reservation reservoirs and hatchery background samples from the Black Canyon Trout Farm, southwestern Idaho and northern Nevada, 2007, 2009, and 2013.—Continued

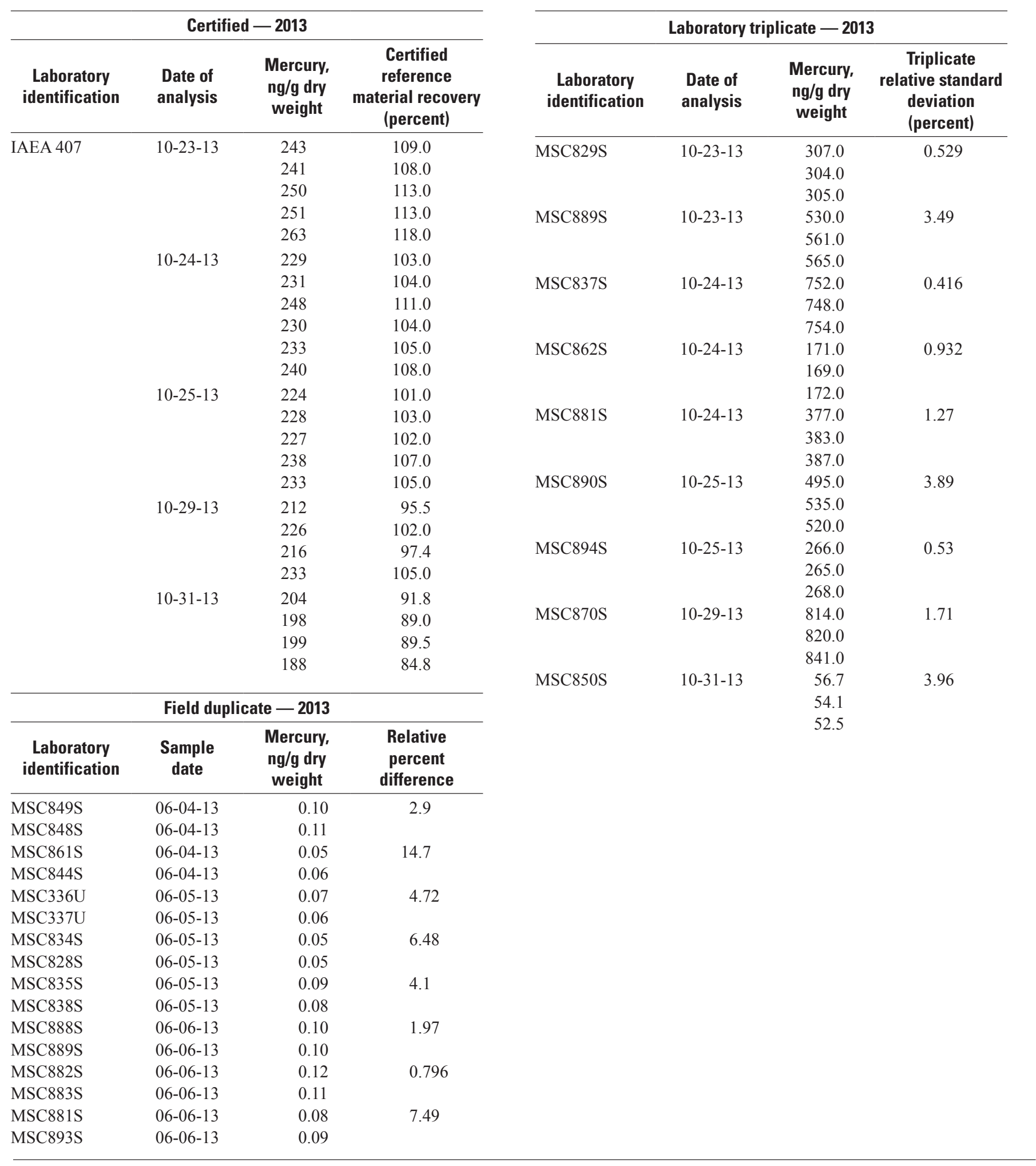


Publishing support provided by the U.S. Geological Survey Science Publishing Network, Tacoma Publishing Service Center

For more information concerning the research in this report, contact the Director, Idaho Water Science Center

U.S. Geological Survey

230 Collins Road

Boise, Idaho 83702

http://id.water.usgs.gov 


\section{总}

